\title{
Denture hygiene among inhabitants of the Lublin province
}

\section{Higiena uzupełnień protetycznych wśród mieszkańców województwa lubelskiego}

\author{
Leszek Szalewski ${ }^{1, A-F} \oplus$, Aneta Kamińska ${ }^{2, A-B, D-F} \oplus$, Justyna Batkowska ${ }^{3, C, E-F \oplus}$, Adrian Deas ${ }^{4, C-F \oplus}$, \\ Katarzyna Sarna-Boś2,B,E-F \\ ${ }^{1}$ Department of Integrated Dentistry of Developmental Age, Medical University, Lublin, Poland \\ 2 Department of Dental Prosthetics, Medical University, Lublin, Poland \\ ${ }^{3}$ Institute of Biological Basis of Animal Production, University of Life Science, Lublin, Poland \\ ${ }^{4}$ Institute of Genetics and Animal Biotechnology of the Polish Academy of Sciences, Poland \\ A - Research concept and design, B - Collection and/or assembly of data, C - Data analysis and interpretation, \\ $D$ - Writing the article, E - Critical revision of the article, F - Final approval of article
}

Szalewski L, Kamińska A, Batkowska J, Deas A, Sarna-Boś K. Hygiene of dentures among the inhabitants of the Lublin province. Med Og Nauk Zdr. 2020; 26(4): 390-396. 10.26444/monz/130547

\section{Abstract}

Objectives. Dentures, like the patient's own teeth, require the necessary hygienic procedures to keep them in good condition. The aim of the study was to analyze selected sociodemographic features, as well as awareness and hygiene behaviours in patients from the Lublin province who use fixed and removable dentures.

Materials and method. The cross-sectional study material consisted of 1,200 questionnaires distributed among people residing in the Lublin province using removable or fixed dentures. The study was conducted between June 2016 - June 2017 in randomly selected private dental offices providing private and National Health Fund dental services in the Lublin province to patients using dentures.

Results. The majority of respondents (51.6\%) disinfected their dentures, with women more often than men providing a positive answer. Almost a half (45.6\%) of respondents used dentures 24 hours a day, $36.7 \%$ stored their dentures overnight in a container with liquid, $16.3 \%$ stored them in a dry container, and others (1.4\%) in a different way. A manual toothbrush was indicated by $68.3 \%$ of respondents as the method they used for daily oral hygiene. Men significantly more often used other types of brushes (electric or sonic) than women. Men also more often used dental floss.

Conclusions. The dentist issuing denture should provide the patient with detailed recommendations regarding its use and proper hygiene because patients' knowledge on this subject is insufficient.

\section{Key words}

oral hygiene, removable partial dentures (RPDs), fixed dentures

\section{- Streszczenie}

Cel pracy. Uzupełnienia protetyczne tak jak zęby własne pacjenta wymagają niezbędnych zabiegów higienizacyjnych, pozwalających utrzymać uzębienie resztkowe i protezy w dobrym stanie. Celem badań była analiza wybranych cech socjodemograficznych oraz świadomości i zachowań higienizacyjnych pacjentów z województwa lubelskiego użytkujących protezy stałe i ruchome.

Materiał i metody. Materiał do badań stanowiło 1200 formularzy ankietowych, wypełnionych przez osoby zamieszkałe na terenie województwa lubelskiego korzystające z ruchomych i/lub stałych protez zębowych.

Badanie przeprowadzono w prywatnych gabinetach stomatologicznych na terenie województwa lubelskiego wśród pacjentów użytkujących protezy.

Wyniki. Większość ankietowanych (52,9\%) dezynfekuje swoje protezy, przy czym na odpowiedź wpływa płeć - częściej odpowiedź twierdzącą wskazywały kobiety. Prawie połowa (47,1\%) ankietowanych użytkuje protezy całodobowo, 37,2\% przechowuje swoje protezy przez noc w pojemniku z płynem, $14,5 \%$ - w pojemniku na sucho, pozostali $(1,2 \%)$ w inny sposób. Szczoteczkę manualną wskazało $74,8 \%$ ankietowanych jako tę, którą używają do codziennej higieny jamy ustnej. Mężczyźni istotnie częściej korzystali z innych szczoteczek (elektrycznej lub sonicznej) niż kobiety. Również mężczyźni częściej używają nici dentystycznych.

Wnioski. Lekarz dentysta oddający protezę powinien przekazywać pacjentowi szczegółowe zalecenia dotyczące jej użytkowania oraz prawidłowej higieny, ponieważ wiedza pacjentów na ten temat jest niewystarczająca.

\section{Słowa kluczowe}

higiena jamy ustnej, protezy ruchome, protezy stałe
Address for correspondence: Leszek Szalewski, Department of Integrated Dentistry of Developmental Age, Medical University, Lublin, Poland

E-mail: Leszek.Szalewski@umlub.pl

Received: 14.07.2020; accepted: 17.11.2020; fist published: 01.12.2020

\section{INTRODUCTION}

The increase in life expectancy in Poland and neglect in dental care from an early age [1] has resulted in an increase in the number of complete and partial edentulous patients. Denture rehabilitation of these patients should be based on 
fixed or removable dentures with bridges. Another effective solution is an implant-based prosthetic rehabilitation in the case of missing abutments teeth, or the inability to use residual teeth as abutments. In Poland, due to financial reasons, many people opt for denture treatment refunded by the National Health Fund which covers the costs of removable mucosa-supported dentures (complete and/or partial dentures).

Dentures, like the patient's own teeth, require necessary hygienic procedures to maintain the residual teeth and dentures in good condition [2]. Patients during the last visit for prosthetic treatment, in particular those receiving their first denture, should be instructed by the dentist about the proper use and care of the dentures. It is very important in the case of removable dentures to inform patients about the necessity to remove them for at least 6-8 hours a day and to store them in a dry environment [3]. Patients should be aware that acceptance of the finished dentures does not terminate the treatment process, but they should remain under the care of the dentist and report for designated visits, and not only in the event of an emergency, e.g., breaking/ fracture of the denture $[4,5]$. In the case of prosthetic bridges, however, patients should be informed about the need to use special dental floss without which it is impossible to keep the restoration clean.

Surveys conducted among patients using fixed and removable dentures indicate that there is a problem with maintaining the correct hygiene of prosthetic restorations $[4,6]$. This may be due to the age of the majority of patients, and their physical limitations or insufficient information provided by dentists. It is very important that dentists are aware that even the best denture work if used improperly can lead to prosthetic stomatopathy and other complications [7].

\section{OBJECTIVE}

The aim of the study was to analyze selected sociodemographic features, as well as awareness and hygiene behaviours in patients from the Lublin province who use fixed or removable dentures.

\section{MATERIALS AND METHOD}

The study material consisted of 1,200 questionnaires distributed among people residing in the Lublin province, who used removable or fixed dentures. The inclusion criteria were the use of prosthetic dentures and place of residence in the Lublin province. The study was conducted between June 2016 - June 2017. 1,170 correctly filled forms were considered valid and served as a source of data. The study was conducted in randomly selected private dental offices which provided private and National Health Fund dental services to patients using dentures in the Lublin province The participants completed the questionnaire independently in their own time, without the supervision of the office staff. The characteristics of the study group, taking into account gender, age, education, place of residence, income and type of dental care, are presented in Table 1 . The study also analyzed the type of health care (National Health Fund or private), duration of denture usage, any repairs of dentures, use of preparations for cleaning and disinfection of dentures,
Table 1. Characteristics of the surveyed group of patients

\begin{tabular}{|c|c|c|c|}
\hline Category & & $\mathrm{n}$ & $\%$ \\
\hline \multirow{2}{*}{ Gender } & Male & 410 & 35.0 \\
\hline & Female & 760 & 65.0 \\
\hline \multirow{4}{*}{ Age } & $18-35$ & 112 & 10.0 \\
\hline & $36-50$ & 333 & 28.0 \\
\hline & $51-65$ & 479 & 41.0 \\
\hline & Over 66 & 246 & 21.0 \\
\hline \multirow{4}{*}{ Education } & Primary school & 98 & 8.0 \\
\hline & Vocational & 227 & 19.0 \\
\hline & High school & 524 & 45.0 \\
\hline & University & 321 & 27.0 \\
\hline \multirow{4}{*}{ Residence } & Village & 279 & 24.0 \\
\hline & Town up to $50 \mathrm{~K}$ & 228 & 19.0 \\
\hline & City $50-200 K$ & 167 & 14.0 \\
\hline & City over $200 \mathrm{~K}$ & 496 & 42.0 \\
\hline \multirow{4}{*}{ Monthly income (PLN) per person } & Up to 500 PLN & 80 & 7.0 \\
\hline & 500-900 PLN & 268 & 23.0 \\
\hline & $1,000-1,500$ PLN & 457 & 39.0 \\
\hline & Over 1500 PLN & 365 & 31.0 \\
\hline \multirow{4}{*}{$\begin{array}{l}\text { Type of dental care most often used by } \\
\text { the patient }\end{array}$} & Public & 620 & 52.9 \\
\hline & Private & 491 & 42.0 \\
\hline & Both & 47 & 4.0 \\
\hline & None & 13 & 1.1 \\
\hline \multirow{3}{*}{ What kind of denture are you using? } & Fixed & 478 & 40.9 \\
\hline & Removable & 576 & 49.2 \\
\hline & Both & 116 & 9.9 \\
\hline
\end{tabular}

method of storing dentures at night, causes and frequency of follow-up visits, and the level of subjective evaluation of satisfaction with the dentures used. All procedures performed involving the participants were in accordance with the ethical standards of the Institutional and/or National Research Committee, and with the 1964 Helsinki Declaration and its later amendments, or comparable ethical standards. The authors obtained the informed consent of patients/caregivers of patients to participate in the study.

The data was prepared using the SPSS 20.0 PL statistical package [8]. The Kolmogorov-Smirnov test was used to analyze the normality of the distribution of the obtained data. Because a statistically significant data discrepancy was obtained from the normal distribution, further analyses were carried out using non-parametric tests $\left(\chi^{2}\right)$. Spearman nonparametric correlation coefficients were also estimated. The value of $\mathrm{p}<0.05$ was adopted as the threshold of statistical significance.

\section{RESULTS}

More than a half of the respondents (52.9\%) used only public dental care as part of the benefits provided by the National Health Fund (NFZ), while $42.0 \%$ used only private dental care. The analysis did not reveal the relationship between gender and the choice of type of dental care. There was, however, a significant relevance between education and the choice of type of care - the lower the level of education of 
respondents, the more often they indicated public dental care. In turn, with age, patients were less likely to use any dental care. A relationship between the place of residence and income was also shown - the larger the city and the higher income per one person, the more often the respondents chose private dental care (Tab. 2).

Patients using removable dentures were more likely to use public dental care, whilre users of fixed dentures more often opted for private care (Tab. 3). A more frequent selection of fixed dentures was shown in correlation with an increase in the level of education. Both prosthetic restorations (fixed and removable) were more often used by people who had had dentures made more than 10 years previously. In the question about the repair of dentures, the respondents were able to make multiple selections, and from the analysis of these data it followed that removable denture had to be repaired statistically more often; however, dentures were damaged more often among patients using both types of dentures (fixed and removable).

Among 457 respondents using removable dentures, 38.7\% used partial acrylic dentures, 53.2\% used complete dentures and only $8.1 \%$ skeletal dentures (Tab. 4). The majority of respondents $(51.6 \%)$ disinfected their dentures, the answer was dependent on gender - women answered affirmatively more often. A statistically significant correlation was also found in the case of age and education level and the reversedependent in the case of income (Tab. 5). Almost half (45.6\%) of respondents used dentures 24 hours a day, 36.7\% stored their dentures overnight in a container with liquid, $16.3 \%$ stored them in a dry container, while others (1.4\%) stored them in a different way. Removable dentures were most often ordered as part of public dental care, and a positive correlation was shown with gender, with men more often using this form of care, age, education, place of residence and income.
In the case of fixed dentures, most respondents used prosthetic crowns (55.0\%), bridges (31.2\%), and $13.8 \%$ of respondents had both fixed dentures? (Tab. 6). A manual toothbrush was indicated by $68.3 \%$ of respondents as the method they used for daily oral hygiene. Men significantly more often used other brushes (electric or sonic) than women (Tab. 7). Men also used dental floss more often. The use of dental floss decreased with the age of the respondents, and the use of floss was also noticeably reduced in patients with lower education levels, smaller cities and lower income.

\section{DISCUSSION}

The use of removable dentures is often associated with prosthetic stomatopathies for several reasons: improper preparation of prostheses and/or improper habits of patients related to the cleaning and storing of dentures.

An excessively prolonged period of use of the same dentures is not conducive to proper prosthetic rehabilitation. Almost $1 / 3$ of respondents used their prostheses in the range of $5-10$ years, and $23.25 \%$ of respondents used them for over 10 years. According to the results of a review carried out by Akinyamoju et al.[9], dentures should not be used for more than 5 years because after this period they may have a detrimental effect on oral tissues. Research conducted in Brazil by Coelho et al. [10] showed that, respectively, 24.53\% and over $50 \%$ of respondents used their dentures for more than 20 years. Also, in studies by Cakan et al. [11], 65\% of patients used their dentures for more than 6 years.

$54.79 \%$ of respondents reported to the dentist only if a problem occurred, while only $25.98 \%$ of patients reported regularly for follow-up visits every 6 months. This is confirmed by the results of research conducted by Marchini et al. [12] in which only $23 \%$ of the patients reported back to the dentist

Table 2. Type of care used according to the analyzed categories of respondents

\begin{tabular}{|c|c|c|c|c|c|c|c|c|c|c|c|c|}
\hline \multirow{2}{*}{ Category } & & \multicolumn{2}{|c|}{ Public } & \multicolumn{2}{|c|}{ Private } & \multicolumn{2}{|c|}{ Both } & \multicolumn{2}{|c|}{ None } & \multirow{2}{*}{$x^{2}$ (p-value) } & \multirow{2}{*}{$\begin{array}{c}\text { Fisher } \\
\text { (p-value) }\end{array}$} & \multirow{2}{*}{ V-Crammera } \\
\hline & & $\mathrm{n}$ & $\%$ & $\mathrm{n}$ & $\%$ & $\mathrm{n}$ & $\%$ & $\mathrm{n}$ & $\%$ & & & \\
\hline \multirow{2}{*}{ Gender } & Male & 218 & 35.2 & 169 & 34.4 & 18 & 38 & 5 & 58 & \multirow{2}{*}{0.910} & \multirow{2}{*}{0.8846} & \multirow{2}{*}{0.021} \\
\hline & Female & 402 & 64.8 & 322 & 65.6 & 29 & 62 & 7 & 42 & & & \\
\hline \multirow{3}{*}{ Age } & $18-35$ & 20 & 3.0 & 88 & 18.0 & 4 & 8.0 & 0 & 0 & \multirow{3}{*}{0.000} & \multirow{3}{*}{0.000} & \multirow{3}{*}{0.2313} \\
\hline & $36-50$ & 130 & 21.0 & 188 & 38.0 & 8 & 17.0 & 7 & 58 & & & \\
\hline & Over 66 & 190 & 31.0 & 36 & 7.0 & 20 & 43.0 & 0 & 0 & & & \\
\hline \multirow{4}{*}{ Education } & Primary school & 66 & 11.0 & 32 & 7.0 & 0 & 0.0 & 0 & 0.0 & \multirow{4}{*}{0.000} & \multirow{4}{*}{0.000} & \multirow{4}{*}{0.2254} \\
\hline & Vocational education & 176 & 28.0 & 51 & 10.0 & 0 & 0.0 & 0 & 0.0 & & & \\
\hline & High school & 291 & 47.0 & 202 & 41.0 & 16 & 36.4 & 12 & 100.0 & & & \\
\hline & University & 87 & 14.0 & 206 & 42.0 & 28 & 63.6 & 0 & 0.0 & & & \\
\hline \multirow{3}{*}{ Residence } & Town up to $50 \mathrm{~K}$ & 141 & 23.0 & 56 & 11.0 & 24 & 51.0 & 7 & 58.0 & \multirow{3}{*}{0.000} & \multirow{3}{*}{0.000} & \multirow{3}{*}{0.2048} \\
\hline & City $50-200 \mathrm{~K}$ & 75 & 12.0 & 88 & 18.0 & 3 & 6.0 & 1 & 8.0 & & & \\
\hline & City over $200 \mathrm{~K}$ & 200 & 32.0 & 276 & 56.0 & 16 & 34.0 & 4 & 33.0 & & & \\
\hline \multirow{4}{*}{ Monthly income (PLN) per person } & Up to 500 PLN & 60 & 10.0 & 20 & 5.0 & 0 & 0.0 & 0 & 0.0 & \multirow{4}{*}{0.000} & \multirow{4}{*}{0.000} & \multirow{4}{*}{0.241} \\
\hline & 500-900 PLN & 260 & 42.0 & 55 & 11.0 & 4 & 9.0 & 0 & 0.0 & & & \\
\hline & $1000-1500$ PLN & 260 & 42.0 & 173 & 35.0 & 19 & 40.0 & 5 & 42.0 & & & \\
\hline & Over 1500 PLN & 91 & 16.0 & 243 & 49.0 & 24 & 51.0 & 7 & 58.0 & & & \\
\hline
\end{tabular}

${ }^{* *}$ Correlation significant at 0.01 (two-sided) 
Table 3. What type of denture do you use?

\begin{tabular}{|c|c|c|c|c|c|c|c|c|c|c|}
\hline \multirow{2}{*}{ Category } & & \multicolumn{2}{|c|}{ Fixed } & \multicolumn{2}{|c|}{ Removable } & \multicolumn{2}{|c|}{ Both } & \multirow{2}{*}{ x2 (p-value) } & \multirow{2}{*}{$\begin{array}{c}\text { Fisher } \\
\text { (p-value) }\end{array}$} & \multirow{2}{*}{ V-Crammera } \\
\hline & & $\mathrm{n}$ & $\%$ & $\mathrm{n}$ & $\%$ & $\mathrm{n}$ & $\%$ & & & \\
\hline \multirow{3}{*}{$\begin{array}{l}\text { Please select the type of } \\
\text { dental care you use most } \\
\text { often }\end{array}$} & Public & 135 & 28.24 & 416 & 72.22 & 69 & 59.48 & \multirow{3}{*}{0.000} & \multirow{3}{*}{0.000} & \multirow{3}{*}{0.335} \\
\hline & Both & 19 & 3.97 & 16 & 2.78 & 12 & 10.34 & & & \\
\hline & None & 5 & 1.05 & 0 & 0.00 & 7 & 6.03 & & & \\
\hline \multirow{3}{*}{ Education } & Vocational & 56 & 11.72 & 163 & 28.30 & 8 & 6.90 & \multirow{3}{*}{0.000} & & \multirow{3}{*}{0.301} \\
\hline & High school & 193 & 40.38 & 247 & 42.88 & 84 & 72.41 & & & \\
\hline & University & 217 & 45.40 & 84 & 14.58 & 20 & 17.24 & & & \\
\hline \multirow{2}{*}{$\begin{array}{l}\text { How long have you been } \\
\text { using dentures? }\end{array}$} & Less than 5 years & 258 & 53.97 & 214 & 37.15 & 28 & 24.14 & \multirow[b]{2}{*}{0.000} & & \multirow[b]{2}{*}{0.204} \\
\hline & 5-10 years & 164 & 34.31 & 169 & 29.34 & 61 & 52.59 & & & \\
\hline \multirow{6}{*}{$\begin{array}{l}\text { Did the dentures require } \\
\text { repair during this time? } \\
\text { (what kind?) }\end{array}$} & Yes, after breaking & 28 & 5.9 & 218 & 32.06 & 36 & 29.51 & \multirow{6}{*}{0.000} & & \multirow{6}{*}{0.297} \\
\hline & Yes, adding removed tooth & 48 & 10.00 & 174 & 25.59 & 20 & 16.39 & & & \\
\hline & Yes, relining the denture & 8 & 1.7 & 40 & 5.88 & 8 & 6.56 & & & \\
\hline & Yes, other, e.g., recementing & 52 & 10.88 & 20 & 2.94 & 4 & 3.28 & & & \\
\hline & Yes, adding removed tooth and after breaking & 4 & 0.84 & 51 & 9,17 & 8 & 6,9 & & & \\
\hline & No, denture did not require repair & 338 & 70.71 & 220 & 39.57 & 56 & 48.28 & & & \\
\hline \multirow{4}{*}{$\begin{array}{l}\text { Which one of the dentures } \\
\text { required repair? }\end{array}$} & None & 346 & 72.38 & 198 & 4.38 & 68 & 58.62 & \multirow{4}{*}{0.000} & & \multirow{4}{*}{0.273} \\
\hline & Upper denture & 88 & 18.41 & 210 & 36.46 & 28 & 24.14 & & & \\
\hline & Lower denture & 32 & 6.69 & 93 & 15.15 & 20 & 17.24 & & & \\
\hline & Both & 12 & 2.51 & 75 & 13.02 & 0 & 0.00 & & & \\
\hline \multirow{2}{*}{$\begin{array}{l}\text { Are you satisfied with the } \\
\text { dentures? }\end{array}$} & Yes & 374 & 78.90 & 438 & 76.04 & 84 & 72.41 & \multirow[b]{2}{*}{0.070} & \multirow[b]{2}{*}{0.087} & \multirow[b]{2}{*}{0.061} \\
\hline & No & 31 & 6.54 & 45 & 7.81 & 4 & 3.45 & & & \\
\hline \multirow{4}{*}{$\begin{array}{l}\text { How often do you go to } \\
\text { control visits at the dentist? }\end{array}$} & When I see a problem & 183 & 39.61 & 378 & 66.08 & 80 & 68.97 & \multirow{4}{*}{0.000} & & \\
\hline & Every six months & 214 & 46.32 & 69 & 12.06 & 21 & 18.10 & & & 0283 \\
\hline & I don't go to control visits & 45 & 9.74 & 105 & 18.36 & 4 & 3.45 & & & 0.283 \\
\hline & In another period & 20 & 4.33 & 20 & 3.50 & 11 & 9.48 & & & \\
\hline
\end{tabular}

${ }^{* *}$ Correlation significant at 0.01 (two-sided)

within 10 years after receiving their denture. The problem indicated most by the respondents related to fracture of the denture $(24.10 \%)$ and tooth addition after extraction of an own tooth (20.68\%). Denture fracture can often be caused by anocclusal problems, which can be corrected during followup visits to prevent damage to the dentures, or overstressing own teeth in the case of partial dentures [13].

Many studies have confirmed the fact that dentists do not give advice about the proper hygiene of dentures [14-16]. Proper hygiene of removable dentures should be carried out daily with a few abrasive cleansers by the patient, and once a year a professional cleaning procedure should be carried out by a dentist or hygienist using ultrasonic devices [14]. The effect of cleaning dentures can be improved by using, in addition to brushing, effervescent cleaning tablets [4]. The majority of respondents $(78.0 \%)$ used abrasive toothpaste to clean their dentures, which is also reflected in other studies $[11,17]$. In vitro studies by Izumida et al. [18] confirm that the use of toothpastes causes the greatest surface roughness of the acrylic material, which encourages the adhesion of bacterial plaque to the surface of the denture.

$2 / 3$ of respondents indicated that they disinfect their dentures by mostly using cleaning and disinfecting tablets, hot water or hydrogen peroxide. Boiling water should not be used because it does not lead to proper disinfection and can also cause deformation of the denture [14]. Preparations containing sodium hypochlorite are considered the most effective, as confirmed by in vitro studies [16].

$45.6 \%$ of respondents did not remove their removable dentures at night, which may contribute to the formation of inflammation of the mucous membrane due to the accumulation of bacterial plaque [12]. In turn, as many as $36.7 \%$ of respondents stored their dentures at night in a container with liquid, thus allowing the growth of microorganisms on the surface of restorations. Only $16.3 \%$ of respondents stored dentures in a dry environment in accordance with the applicable rules. Incorrect use of dentures at night has been demonstrated in many surveys worldwide $[2,3,5,11]$.

Patients using fixed dentures are often convinced that they should take care of them in the same way as their natural teeth. $68.3 \%$ of respondents used manual brushes for daily oral hygiene, electric and sonic toothbrushes were used by $29.6 \%$ and $2.0 \%$, respectively. This may be due to the fact that there is a myth about decementation of prosthetic works by using electric or sonic brushes. There is no evidence in support of this thesis in the literature, and there are papers 
Table 4. Questions about removable dentures.

\begin{tabular}{|c|c|c|c|c|c|c|c|c|}
\hline \multicolumn{2}{|l|}{ Survey questions } & \multicolumn{7}{|c|}{ Category } \\
\hline \multirow{2}{*}{$\begin{array}{l}\text { What kind of removable } \\
\text { denture do you use? }\end{array}$} & & full denture & acrylic partial denture & skeletal denture & & & & \\
\hline & $\mathrm{n}$ & 243 & 177 & 37 & & & & \\
\hline \multirow{2}{*}{$\begin{array}{l}\text { What substances do you use to } \\
\text { clean the denture? }\end{array}$} & & toothpaste & soap & dishwasher liquid & other & & & \\
\hline & $n$ & 446 & 70 & 8 & 36 & & & \\
\hline \multirow{3}{*}{ Do you disinfect your dentures? } & & yes, once a week & yes, every two weeks & yes, less frequently & no & & & \\
\hline & $n$ & 204 & 39 & 52 & 277 & & & \\
\hline & $\%$ & 35.7 & 6.8 & 9.1 & 48.4 & & & \\
\hline \multirow{2}{*}{$\begin{array}{l}\text { What do you use to disinfect } \\
\text { your dentures? }\end{array}$} & & hot water & soda solution & Corega tabs & Octenisept & mouthwash & $\begin{array}{l}\text { hydrogen } \\
\text { peroxide }\end{array}$ & nothing \\
\hline & $n$ & 24 & 12 & 112 & 12 & 8 & 31 & 113 \\
\hline \multirow{3}{*}{$\begin{array}{l}\text { Do you use special preparations } \\
\text { for dentures and mucous } \\
\text { membranes? }\end{array}$} & & $\begin{array}{l}\text { creams/glues for } \\
\text { dentures (e.g., } \\
\text { Protefix) }\end{array}$ & $\begin{array}{l}\text { denture cleaning } \\
\text { tablets (e.g., Corega) }\end{array}$ & $\begin{array}{l}\text { gel for irritated } \\
\text { gums (e.g., Sachol, } \\
\text { Dentosept) }\end{array}$ & $\begin{array}{l}\text { cleaning } \\
\text { brushes }\end{array}$ & $\begin{array}{l}\text { other } \\
\text { methods }\end{array}$ & $\begin{array}{l}\text { I don't use } \\
\text { any }\end{array}$ & \\
\hline & $\mathrm{n}$ & 85 & 132 & 58 & 72 & 4 & 115 & \\
\hline & $\%$ & 18.2 & 28.3 & 12.4 & 15.5 & 0.9 & 24.7 & \\
\hline \multirow{3}{*}{$\begin{array}{l}\text { How do you store your } \\
\text { dentures at night? }\end{array}$} & & $\begin{array}{l}\text { I use it } 24 / 7, \text { I don't } \\
\text { take it out at night }\end{array}$ & $\begin{array}{l}\text { in a container with } \\
\text { water/liquid }\end{array}$ & in a dry container & differently & & & \\
\hline & $\mathrm{n}$ & 261 & 210 & 93 & 8 & & & \\
\hline & $\%$ & 45.6 & 36.7 & 16.3 & 1.4 & & & \\
\hline \multirow[t]{3}{*}{$\begin{array}{l}\text { Did you have the dentures } \\
\text { made based on the National } \\
\text { Health Fund insurance? }\end{array}$} & & $\begin{array}{l}\text { yes, I have made } \\
\text { dentures based only } \\
\text { on NHF insurance }\end{array}$ & $\begin{array}{l}\text { yes, I have dentures } \\
\text { made based on } \\
\text { NHF insurance with } \\
\text { additional cost }\end{array}$ & $\begin{array}{l}\text { yes, but if denture was } \\
\text { not available from } \\
\text { NHF insurance I have } \\
\text { it made it privately }\end{array}$ & $\begin{array}{l}\text { I do not } \\
\text { have } \\
\text { dentures } \\
\text { made } \\
\text { on NHF } \\
\text { insurance }\end{array}$ & & & \\
\hline & $n$ & 357 & 57 & 73 & 58 & & & \\
\hline & $\%$ & 64.3 & 10.3 & 13.2 & 12.3 & & & \\
\hline \multirow[t]{3}{*}{$\begin{array}{l}\text { Did dentures require } \\
\text { adjustments? }\end{array}$} & & $\begin{array}{l}\text { no, denture didn't } \\
\text { require adjustment }\end{array}$ & $\begin{array}{l}\text { yes, denture required } \\
\text { small adjustment }\end{array}$ & $\begin{array}{l}\text { yes, denture required } \\
\text { several adjustments }\end{array}$ & $\begin{array}{l}\text { yes, but } \\
\text { even after } \\
\text { adjustments } \\
\text { I'm not } \\
\text { satisfied } \\
\text { with } \\
\text { dentures } \\
\text { ordered }\end{array}$ & & & \\
\hline & $n$ & 227 & 222 & 70 & 41 & & & \\
\hline & $\%$ & 40.5 & 39.6 & 12.5 & 7.3 & & & \\
\hline
\end{tabular}

* percentage of all responses given

clearly showing that the use of electric and sonic brushes does not affect the degradation of cement of fixed dentures [19]. Significantly more men used power brushes (electric / sonic), which may be due to the fact that men are more likely to choose novelty and gadgets than women. As shown by numerous studies collected in our own review of literature, it can be concluded that the use of electric and/or sonic brushes improves oral hygiene [20].

A half (53.3\%) of the patients who had fixed dentures did not use dental floss, only $22.7 \%$ of respondents used dental floss intende; however, as many studies have emphasized, brushing and flossing should be a standard in everyday hygiene, with rinses used as an addition [21].

Incorrect hygiene and storage of dentures is most likely related to the lack of information provided by the dentist to patients [2]. This problem is important because the society's knowledge about the hygiene of dentures is negligible. Older people are most often the patients who use removable dentures but are unable to find information about proper denture hygiene.

\section{CONCLUSIONS}

1. The dentist should provide the patient with detailed recommendations regarding the use and proper hygiene of dentures. The recommendations should be in written form clearly understandable by the patients.

2. The dentist should pay attention during check-up visits, especially because most patients skip them and report only when a problem occurs. Regular check-up can prevent damage to the dentures. 
Table 5. Questions about removable dentures.

\begin{tabular}{|c|c|c|c|c|c|c|}
\hline Category & & Gender & Age & Education & $\begin{array}{l}\text { Place of } \\
\text { residence }\end{array}$ & $\begin{array}{l}\text { Monthly income } \\
\text { (PLN) per person }\end{array}$ \\
\hline What kind of removable denture do you use? & x2 (p-value) & 0.782 & 0.000 & 0.000 & 0.000 & 0.000 \\
\hline \multirow{2}{*}{ What substances do you use to clean the denture? } & x2 (p-value) & 0.959 & 0.000 & 0.000 & 0.000 & 0.000 \\
\hline & V Cramera & 0.033 & 0.180 & 0.207 & 0.213 & 0.158 \\
\hline \multirow{2}{*}{ Do you disinfect your dentures? } & x2 (p-value) & 0.517 & 0.000 & 0.003 & 0.000 & 0.000 \\
\hline & V Cramera & 0.063 & 0.209 & 0.121 & 0.220 & 0.151 \\
\hline \multirow{2}{*}{ What do you use to disinfect your dentures? } & $x^{2}$ (p-value) & 0.940 & 0.000 & 0.000 & 0.000 & 0.000 \\
\hline & V Cramera & 0.075 & 0.340 & 0.279 & 0.393 & 0.384 \\
\hline \multirow{2}{*}{ Do you use special preparations for dentures and mucous membranes? } & x2 (p-value) & 0.978 & 0.000 & 0.000 & 0.000 & 0.000 \\
\hline & V Cramera & 0.041 & 0.207 & 0.266 & 0.269 & 0.245 \\
\hline \multirow{2}{*}{ How do you store your dentures at night? } & X2 (p-value) & 0.856 & 0.05436 & 0.000 & 0.005 & 0.000 \\
\hline & V Cramera & 0.037 & 0.099 & 0.219 & 0.117 & 0.225 \\
\hline \multirow{2}{*}{ Did you order the dentures based on National Health Fund insurance? } & $x^{2}$ (p-value) & 0.829 & 0.000 & 0.000 & 0.000 & 0.000 \\
\hline & V Cramera & 0.040 & 0.286 & 0.213 & 0.187 & 0.204 \\
\hline \multirow{2}{*}{ Did dentures require adjustments? } & $x^{2}$ (p-value) & 0.425 & 0.000 & 0.000 & 0.006 & 0.10862 \\
\hline & V Cramera & 0.071 & 0.207 & 0.211 & 0.117 & 0.092 \\
\hline
\end{tabular}

Table 6. Questions about fixed dentures

\begin{tabular}{|c|c|c|c|c|c|}
\hline \multirow[t]{2}{*}{ Survey question } & & \multicolumn{4}{|c|}{ Category } \\
\hline & & crown & bridge & both & \\
\hline \multirow[t]{3}{*}{ What kind of denture do you use? } & $\mathrm{n}$ & 252 & 143 & 63 & \\
\hline & $\% *$ & 55.0 & 31.2 & 13.8 & \\
\hline & & manual & electric & sonic & \\
\hline \multirow[t]{2}{*}{ What kind of toothbrush do you use? } & $\mathrm{n}$ & 302 & 131 & 9 & \\
\hline & & yes, specially designed for the hygiene of bridges & waxed & non-waxed & I don't use it \\
\hline \multirow[t]{3}{*}{ Do you use dental floss? } & $\mathrm{n}$ & 103 & 73 & 36 & 242 \\
\hline & $\%$ & 22.7 & 16.1 & 7.9 & 53.3 \\
\hline & & alcohol-based & based on chlorhexidine & I don't know & I don't use it \\
\hline What kind of mouthwash do you use? & $\mathrm{n}$ & 83 & 67 & 140 & 152 \\
\hline
\end{tabular}

* percentage of all responses given

Table 7. Questions about fixed dentures.

\begin{tabular}{|c|c|c|c|c|c|c|}
\hline Category & & Gender & Age & Education & Place of residence & Monthly income (PLN) per person \\
\hline \multirow{2}{*}{ What kind of denture do you use? } & $x^{2}$ (p-value) & 0.9466 & 0.000 & 0.000 & 0.000 & 0.027 \\
\hline & V Cramera & 0.01548 & 0.21886 & 0.20378 & 0.19043 & 0.12454 \\
\hline What kind of toothbrush do you use? & V Cramera & 0.05539 & 0.23986 & 0.1635 & 0.16216 & 0.16059 \\
\hline Do you use dental floss? & $x^{2}$ (p-value) & 0.46939 & 0.000 & 0.000 & 0.000 & 0.000 \\
\hline \multirow{2}{*}{ What kind of mouthwash do you use? } & x2 (p-value) & 0.39106 & 0.000 & 0.000 & 0.000 & 0.000 \\
\hline & V Cramera & 0.08244 & 0.20943 & 0.24603 & 0.25709 & 0.24923 \\
\hline
\end{tabular}




\section{REFERENCES}

1. Kamińska A, Szalewski L, Batkowska J, Wallner J, Wallner E, Szabelska A, et al. The dependence of dental caries on oral hygiene habits in preschool children from urban and rural areas in Poland. Ann Agric Environ Med. 2016; 23(4): 660-5.

2. Ogunrinde TJ, Opeodu OI. Denture care practice among patients attending the prosthetic clinic in a Nigerian teaching hospital. Niger Med J. 2015; 56(3): 199-203.

3. Szalewski L, Pietryka-Michałowska E, Szymańska J. Oral hygiene in patients using removable dentures. Polish J Public Health 2017; 127(1): $28-31$.

4.Etman M, Bikey D. Clinical performance of removable partial dentures: A retrospective clinical study. Open Journal of Stomatology, 2012; 2(3): 173-181. doi: 10.4236/ojst.2012.23032

5. Goguță L, Lungeanu D, Jivănescu A. Removable dentures treatment satisfaction of patients with type-2 diabetes, Romanian J Diab Nutr Met Diseas 2018; 25(3): 277-282. doi: https://doi.org/10.2478/ rjdnmd-2018-0032

6. Bidra A, Daubert D, Garcia L, et al. Clinical practice guidelines for recall and maintenance of patients with tooth-borne and implant-borne dental restorations. J Prosthodont. 2015; 25(Suppl 1): S32-S40.

7. Jaworska-Zaremba M, Mierzwińska-Nastalska E, Burzyńska B, Swoboda-Kopeć E, Sikora M. Clinical assessment of Citrosept Dental effectiveness in treatment of Candida-associated denture stomatitis, in patients using removable acrylic dentures. Prosthodontics. 2018; 68(2): 200-210.

8. IBM: Corp. Released, IBM SPSS Statistics for Windows, Version 2040 , IBM Corp., Armonk, NY, 2016.

9. Akinyamoju CA, Dosumu OO, Taiwo JO, Ogunrinde TJ, Akinyamoju AO. Oral health-related quality of life: acrylic versus flexible partial dentures. Ghana Med J. 2019; 53(2): 163-169. doi: 10.4314/gmj.v53i2.12

10. Coelho CMP, Sousa YTCS, Daré AMZ. Denture-related oral mucosal lesions in a Brazilian school of dentistry. J Oral Rehabil. 2004; 31(2): 135-9.
11. Cakan U, Yuzbasioglu E, Kurt H, Kara H, Turunç R, Akbulut A, et al. Assessment of hygiene habits and attitudes among removable partial denture wearers in a university hospital. Niger J ClinPract. 2015; 18(4): 511

12. Marchini L, Tamashiro E, Nascimento DFF, Cunha VPP. Self-reported denture hygiene of a sample of edentulous attendees at a University dental clinic and the relationship to the condition of the oral tissues. Gerodontology. 2004; 21(4): 226-8.

13. Sampa R, Pradip RK, Manabendra M, Saibal KS. Incidence and causes of fracture of acrylic resin complete denture. J Evol Med Dent Scienc, 2014; 69(3): 14787-94.

14. Salerno C, Pascale M, Contaldo M, Esposito V, Busciolano M, Milillo $\mathrm{L}$, et al. Candida-associated denture stomatitis. Med Oral Patol Oral Cirugia Bucal. 2011; e139-43.

15. Krausch-Hofmann S, Cuypers L, Ivanova A, Duyck J. Predictors of Patient Satisfaction with Removable Denture Renewal: A Pilot Study. J Prosthodont. 2018; 27(6): 509-516. doi: 10.1111/jopr.12537

16. Kossioni AE, Hajto-Bryk J, Janssens B, et al. Practical Guidelines for Physicians in Promoting Oral Health in Frail Older Adults. J Am Med Dir Assoc. 2018; 19(12): 1039-1046. doi: 10.1016/j.jamda.2018.10.007

17. Ercalik-Yalcinkaya S, Özcan M. Association between oral mucosal lesions and hygiene habits in a population of removable prosthesis wearers. J Prosthodont. 2015; 24(4): 271-8.

18. Izumida FE, Jorge JH, Ribeiro RC, Pavarina AC, Moffa EB, Giampaolo ET. Surface roughness and Candida albicans biofilm formation on a reline resin after long-term chemical disinfection and toothbrushing. J Prosthet Dent. 2014; 112(6): 1523-9.

19. González-Cabezas C, Hara AT, Hefferren J, Lippert F. Abrasivity testing of dentifrices - challenges and current state of the art. Monographs in Oral Science. 2013; 23: 100-107. doi: 10.1159/000350476

20. Berezowski M, Szalewski L, Włoch K, Szymańska J. The effectiveness of manual and powered toothbrushes. Pol J Public Health. 2017; 127(3): 127-9.

21. Drisko CL. Periodontal self-care: evidence-based support. Periodontol 2000. 2013; 62(1): 243-55. 